\title{
Immune Response to a Hepatitis B DNA Vaccine in Aotus Monkeys: A Comparison of Vaccine Formulation, Route, and Method of Administration
}

\author{
Robert A. Gramzinski, ${ }^{1,2}$ Cynthia L. Brazolot Millan, ${ }^{3}$ \\ Nicanor Obaldia, 2,4 Stephen L. Hoffman, ${ }^{1}$ \\ and Heather L. Davis ${ }^{3,5}$ \\ ${ }^{1}$ Naval Medical Research Institute, Malaria Program, Rockville, \\ Maryland, U.S.A. \\ ${ }^{2}$ Gorgas Memorial Laboratory, Panama City, Panama \\ ${ }^{3}$ Loeb Research Institute, Ottawa, Ontario, Canada \\ ${ }^{4}$ ProMed Trading Inc., Panama City, Panama \\ ${ }^{5}$ Faculties of Health Sciences and Medicine, University of Ottawa, \\ Ottawa, Ontario, Canada
}

Accepted December 15, 1997.

\begin{abstract}
Background: Attempts to optimize DNA vaccines in mice include using different routes of administration and different formulations. It may be more relevant to human use to carry such studies out in nonhuman primates. Here we compare different approaches to delivery of a DNA vaccine against the hepatitis B virus (HBV) in Aotus monkeys.

Materials and Methods: Thirty-two adult Aotus l. lemurinus monkeys divided into 8 groups of four were immunized with $400 \mu \mathrm{g}$ of a DNA vaccine which encoded hepatitis B surface antigen (HBsAg). DNA in saline was administered by intradermal (ID) or intramuscular (IM) injection with needle and syringe, IM injection with the Biojector ${ }^{\boxplus}$ needleless injection system or combined ID (needle) and IM (Biojector). DNA formulated with cationic liposomes (CellFECTIN) ${ }^{\oplus}$ was injected IM with needle or Biojector. DNA with added E. coli DNA (100 $\mu \mathrm{g})$ was injected IM with the Biojector or ID. A ninth group of 4 monkeys was injected IM (needle) with Engerix-B, a commercial vaccine containing recombinant HBsAg $(10 \mu \mathrm{g})$ adsorbed onto alum. Monkeys were boosted in an identical fashion to their prime at 8 weeks, but all received the protein vaccine (Engerix-B) at 16 weeks. Sera was assessed for antibodies against HBsAg
\end{abstract}

(anti-HBs) by enzyme-linked imunosorbent assay (ELISA).

Results: The primary humoral response induced by IM delivery of the DNA vaccine was very poor. In most cases there was no detectable anti-HBs even after 2 DNA doses but the kinetics of the response to subsequent protein indicated that a memory $B$ cell response had been induced. In contrast, following IM-administration of DNA using the Biojector, detectable anti-HBs were observed in 3 of 8 animals and evidence for immunological priming was apparent in an additional 4 of the 8 monkeys. ID injection of DNA vaccine in saline induced a potent antibody response which was augmented 6-fold by the addition of $E$. coli DNA. Combining ID and IM administration did not improve humoral immunity over ID injection alone.

Conclusions: For immunization of primates with DNA vaccines, ID may be a preferable route to IM, although it is not clear whether the Aotus monkey is a relevant model for humans in this respect. Nevertheless, the use of the Biojector needleless injection system may improve responses with IM delivery of DNA vaccines. As well, the immunostimulatory action of $E$. coli DNA may be used to augment the humoral response induced by a DNA vaccine. 


\section{Introduction}

DNA-based immunization has been shown to be highly effective in inducing humoral and cellmediated immunity against numerous viral, bacterial, and parasitic diseases in many animal models. These studies have shown that DNA vaccines may be delivered by various routes in different formulations, including intramuscular (IM) and intradermal (ID) injection of pure plasmid DNA, epidermal delivery of DNA-coated gold particles delivered biolistically with a "genegun," and IM injection of liposome-formulated DNA (1-4). It is difficult to evaluate the relative efficacy of these approaches as there has been very little comparative data using the same antigen and animal model.

Although several DNA vaccines have been shown to be effective in nonhuman primates (5-12), most of these used only IM injection of DNA. As such, it is unclear which routes work in primates and what their relative efficacy might be. In addition, there is generally a need to optimize DNA vaccines in primates in order to reduce the dose of DNA or the number of immunizations required to induce adequate immunity.

We have used the Aotus monkey and a DNA vaccine against the hepatitis $B$ virus (HBV) to evaluate the humoral response against HBV surface antigen (HBsAg) after IM and ID injection of pure plasmid DNA. We have also evaluated the possibility of optimizing these responses through the use of a needleless injection system for IM delivery, the use of liposome-formulated DNA, and the co-administration of Escherichia coli $(E$. coli) DNA to take advantage of the adjuvant effect of immunostimulatory CpG motifs.

\section{Materials and Methods}

\section{Monkeys}

Adult male and female Aotus lemurinus lemurinus (karyotype VIII or IX) monkeys (weight 650$1000 \mathrm{~g}$ ) were maintained in the animal facility of the Gorgas Memorial Laboratory in Panama City, Panama. All A. l. lemurinus monkeys were caught wild on the Isthmus of Panama. Upon arrival at the laboratory, each animal was examined, weighed, and sexed, identified by a metal neck tag with an accession number, administered

Address correspondence and reprint requests to: Dr.

Heather L. Davis, Ottawa Civic Hospital, Loeb Research Institute, 725 Parkdale Ave., Ottawa, ON, Canada, KlY 4E9.

Phone: (613) 798-5555 \#7682; Fax: (613) 761-5354;

E-mail: hdavis@lri.ca thiabendazole orally ( $100 \mathrm{mg}$ base $/ \mathrm{kg}$ ), and vaccinated against Herpes simplex, Herpes tamarinus (New England Regional Primate Research Center, Southborough, MA) and Klebsiella pneumoniae (N. Obaldia, Gorgas Memorial Laboratory, Panama City, Panama). Pre-immune sera from all monkeys was negative for pre-existing antibodies against hepatitis B surface antigen. Throughout the course of the study, the monkeys were monitored daily by animal care specialists and no symptoms of general ill health or local adverse reactions at the sites of injection were noted.

Monkeys were housed either singly, as male/ female pairs, or as family units with up to two offspring per adult pair. Room temperature varied seasonally from $26^{\circ}$ to $33^{\circ} \mathrm{C}$, with relative humidity of $75 \%$ to $87 \%$. A ventilation system provided not less than 15 air changes per hour. Illumination in the rooms was white light from midnight to noon, and red light from noon to midnight.

\section{Experimental Groups}

The monkeys were divided randomly into 9 groups of 4 animals each. For 8 groups, the animals were immunized by IM and/or ID injection of an HBsAg-expressing plasmid DNA vaccine, and boosted in an identical manner 8 weeks later. The DNA was given in saline, formulated with cationic liposomes or with added $E$. coli DNA, and delivered with an ordinary needle and syringe (IM and ID) or with a needleless jet injection system (IM only). The ninth group received a commercial vaccine containing recombinant HBsAg at 0 and 8 weeks. All groups received the recombinant $\mathrm{HBsAg}$ vaccine at 16 weeks to evaluate booster or anamnestic responses. Details for the different groups are summarized in Table 1.

\section{Vaccines and Formulations}

PLASMID DNA VACCINE. The DNA vaccine was a plasmid encoding the major protein $(S$, ad subtype) of the HBV envelope under the control of the cytomegalovirus (CMV) immediate early promoter and containing intron $A$ of $C M V$ $\left(\mathrm{pCMV}_{\mathrm{A}}-\mathrm{S}\right.$; provided by G. Widera, PowderJect, Inc., Madison, WI). The plasmid was grown using its kanamycin resistance gene as a selection marker and the DNA was purified on Qiagen anion-exchange chromatography columns (Qiagen GmbH, Hilden, Germany). Purified DNA was 
Table 1. Summary of experimental groups of Aotus monkeys immunized against $\mathbf{H B s} \mathrm{Ag}$

\begin{tabular}{|c|c|c|c|c|}
\hline Group & Gender & Immunogen $^{a}$ & Formulation $^{b}$ & Delivery Route and Method ${ }^{c}$ \\
\hline 1 & $1 \mathrm{~F}, 3 \mathrm{M}$ & DNA & Saline & IM, needle and syringe, 4 sites \\
\hline 2 & $1 \mathrm{~F}, 3 \mathrm{M}$ & DNA & Saline & IM, Biojector, 4 sites \\
\hline 3 & $3 \mathrm{~F}, 1 \mathrm{M}$ & DNA & Liposome & IM, needle and syringe, 4 sites \\
\hline 4 & $1 \mathrm{~F}, 3 \mathrm{M}$ & DNA & Liposome & IM, Biojector, 4 sites \\
\hline 5 & $2 \mathrm{~F}, 2 \mathrm{M}$ & DNA & Saline & ID, needle and syringe, 4 sites \\
\hline 6 & $1 \mathrm{~F}, 3 \mathrm{M}$ & DNA & Saline & $\begin{array}{l}\text { IM, Biojector and ID, needle } \\
\text { and syringe, } 2 \text { sites each }\end{array}$ \\
\hline 7 & $4 \mathrm{M}$ & DNA & E. coli DNA & IM, needle and syringe, 4 sites \\
\hline 8 & $3 \mathrm{~F}, 1 \mathrm{M}$ & DNA & E. coli DNA & ID, needle and syringe, 4 sites \\
\hline 9 & $3 \mathrm{~F}, 1 \mathrm{M}$ & Engerix-B & N/A & IM, needle and syringe, l site \\
\hline
\end{tabular}

${ }^{a}$ DNA $\left(\mathrm{pCMV}_{\mathrm{A}}-\mathrm{S}, 400 \mu \mathrm{g}\right.$ ) was given at 0 and 8 weeks to all monkeys except group 9. All monkeys received Engerix-B (10 $\mu \mathrm{g}$ $\mathrm{HBsAg}+$ alum) at 16 weeks.

${ }^{b}$ DNA was dissolved in saline or was complexed with a cationic liposome (CellFECTIN) at a 10:1 w/w DNA:lipid ratio. DNA formulated with E.coli DNA was dissolved in saline. N/A = not applicable.

${ }^{c}$ Sites for IM were bilateral deltoid and quadriceps. Sites for ID were over lower back.

redissolved in $0.15 \mathrm{M} \mathrm{NaCl}$ at $1 \mathrm{mg} / \mathrm{ml}$ and was stored at or below $-20^{\circ} \mathrm{C}$ until required for injection. At each immunization, animals received a dose of $400 \mu \mathrm{g}$ divided into 4 sites.

LIPID-FORMULATED DNA VACCINE. DNA was combined with CellFECTIN (Life Technologies Inc., Gaithersburg, MD) in a 10:1 w/w DNA:lipid ratio (i.e., $400 \mu \mathrm{g}$ DNA, $40 \mu \mathrm{g}$ lipid in $2 \mathrm{ml}$ total volume). The lipid-DNA solution was vortexed vigorously for $1 \mathrm{~min}$ and allowed to sit undisturbed on ice for $30 \mathrm{~min}$. This formulation was then mixed by gentle inversion immediately prior to loading into the syringe for IM injection.

E. COLI DNA ADJUVANT. E. coli DNA (Sigma \#D2001, St. Louis, MO) was purified by phenol/ chloroform extraction followed by ethanol precipitation. The DNA was boiled for $5 \mathrm{~min}$, quenched on ice, and stored at $-20^{\circ} \mathrm{C}$. Purified $E$. coli DNA was added to the DNA vaccine (100 $\mu \mathrm{g}$ per $400 \mu \mathrm{g}$ dose) prior to administration. The lipopolysaccharide contamination of the $E$. coli DNA was less than $12.5 \mathrm{ng} / \mathrm{mg}$ DNA.

RECOMBINANT HBsAG VACCINE. Engerix-B (SmithKline Beecham, Rixensart, Belgium) is a commercial $\mathrm{HBV}$ vaccine containing yeast-derived recombinant HBsAg protein (ad subtype) adsorbed to alum. This was used for all three immunizations of control animals (Table 1, group 9) and for the third immunization (at week 16) for the 8 groups that first received 2 doses of DNA. At each immunization, animals received $10 \mu \mathrm{g}$ of HBsAg protein in a volume of $0.5 \mathrm{ml}$, which is recommended as a pediatric dose by the manufacturer.

\section{Vaccine Delivery}

ID delivery of DNA vaccines was performed using a $1-\mathrm{ml}$ insulin syringe with a fused $29 \mathrm{G}^{1 / 2}$ needle (Becton-Dickinson, Franklin Lakes, NJ). Animals received a total of $400 \mu \mathrm{g}$ of DNA vaccine $(1 \mathrm{mg} / \mathrm{ml})$ divided among 4 sites (i.e., $100 \mu \mathrm{l}$ per site) in the shaved skin of the lower back.

IM delivery of DNA vaccines $(400 \mu \mathrm{g})$ was also divided into four sites by bilateral injection into the deltoid and quadriceps muscles. Regular needle and syringe delivery (100 $\mu$ l per site at 1 $\mathrm{mg} / \mathrm{ml}$ ) was carried out using a $1-\mathrm{ml}$ insulin syringe with a fused $29 \mathrm{G}^{1} / 2$ needle. Needle-free delivery $(500 \mu \mathrm{l}$ per site at $0.2 \mathrm{mg} / \mathrm{ml})$ used the Biojector needle-free jet injection system (Bioject Inc., Portland, OR). First and second doses were delivered with Biojector syringe sizes 3 and 2 , respectively.

The Engerix-B vaccine was given by a single IM injection into the right quadriceps muscle using a $1-\mathrm{ml}$ insulin syringe.

\section{Evaluation of Humoral Response to $\mathrm{HBs} A \mathrm{~g}$}

Monkeys were bled prior to the first dose to provide a pre-immune sample. Serum or plasma 
was recovered at 2, 4, 6, and 8 weeks following the first dose and at 1, 2, 4, and 8 weeks following each of the second and third doses.

Antibodies specific to HBsAg (anti-HBs) were detected and quantified by end-point dilution enzyme-linked immunosorbent assay (ELISA) on individual samples as follows. A solid phase of plasma-derived HBsAg particles ( $a d$ subtype, $100 \mu \mathrm{l}$ of $1 \mu \mathrm{g} / \mathrm{ml}$ per well, overnight at RT; International Enzymes, Inc., Fallbrook, CA) was used to capture anti-HBs antibodies in the serum $\left(1 \mathrm{hr}\right.$ at $\left.37^{\circ} \mathrm{C}\right)$, which were then detected with HRP-conjugated goat anti-New World monkey IgG (1:10,000 in PBS-Tween, 10\% FCS; $100 \mu \mathrm{l} /$ well, $1 \mathrm{hr}$ at $37^{\circ} \mathrm{C}$; generously provided by Dr. R. Purcell, NIAID, NIH), followed by OPD solution (100 $\mu \mathrm{l} /$ well, $30 \mathrm{~min}$ at room temperature in the dark; Sigma). The reaction was stopped by the addition of sulphuric acid $\left(50 \mu \mathrm{l}\right.$ of $\left.4 \mathrm{~N} \mathrm{H}_{2} \mathrm{SO}_{4}\right)$. End-point titers were defined as the highest serum dilution that resulted in an absorbance value (OD 450) two times greater than that of nonimmune serum with a cut-off value of 0.05 . Pre-immune serum from each animal was used as the negative control for postimmunization samples taken from the same animal.

Anti-HBs titers were expressed as group means \pm standard errors of the mean (SEM) of individual animal values, which were themselves the average of triplicate assays. The relationship between end-point dilution titers and those in milli-International Units/ml $(\mathrm{mIU} / \mathrm{ml})$, as defined by the World Health Organization (WHO), was determined by comparing a panel of Aotus sera against human-derived standards (Monolisa Anti-HBs "Standards," Sanofi Diagnostics Pasteur, Montreal, Canada) using a nonspecies-specific conjugate (Monolisa Anti-HBs Detection Kit, Sanofi Diagnostics Pasteur) and found to be very close to $1: 1$. An antibody titer of $10 \mathrm{mIU} / \mathrm{ml}$ is considered protective against $\mathrm{HBV}$ infection in humans $(13,14)$. For the purpose of this study, we defined seroconversion as a dilution titer greater than 10 .

\section{Results}

Intramuscular Delivery of DNA Vaccines

IM administration of the HBsAg-expressing DNA vaccine (in saline or with lipid) with an ordinary needle and syringe did not result in seroconversion of any monkey, even after 2 doses. However, 4 of 8 animals seroconverted in response to recombinant protein given subsequently, and in three of these, the response appeared faster than after priming with protein (Fig. 1, Panels D and G versus $A$ ), indicating induction of immunological memory.

The anti-HBs response with IM-delivered DNA vaccine was somewhat improved using needle-free jet injection (Biojector). In this case, 3 of 8 animals seroconverted after the second dose of DNA, and there appeared to be immunological priming by the DNA in another four, as evidenced by the rapid response to subsequently delivered protein (Figs. 1E, H, 2). DNA with lipid appeared to be better than DNA in saline with the Biojector.

\section{Intradermal Delivery of DNA Vaccines}

DNA vaccines injected ID induced seroconversion in 3 of 4 monkeys after a single dose (Figs. 1B, 2). The remaining monkey failed to seroconvert even with 2 doses, however, a strong anamnestic response was observed following protein administration.

\section{Combined ID and IM Delivery of DNA Vaccines}

Results with combined IM and ID delivery of the DNA vaccine were very similar to those with ID injection alone, except that the fourth animal seroconverted with the second dose of DNA (Figs. 1F, 2).

\section{Use of E. coli DNA as an Immunostimulant}

The addition of $E$. coli DNA did not improve the humoral response after IM injection (Fig. 1I), but had a strong immunostimulatory effect after ID delivery, where the mean anti-HBs titer after 2 doses of DNA was up to 4-fold higher than DNA vaccine alone (Fig. IC). The immunostimulatory effect of the $E$. coli DNA was even more evident after the protein boost, at which time a 6-fold difference in mean anti-HBs titer was detected (Figs. 1C, 2).

\section{Protein Immunization}

After the initial dose of recombinant HBsAg (Engerix-B), only 1 of 4 monkeys seroconverted, and this was not detected until 6 weeks. All 4 monkeys were seropositive after the second dose of protein, and titers were further increased by the third dose (Figs. 1A, 2).

\section{Discussion}

\section{Choice of Animal Model}

There are two basic factors that may influence the response to a given DNA vaccine in a given 


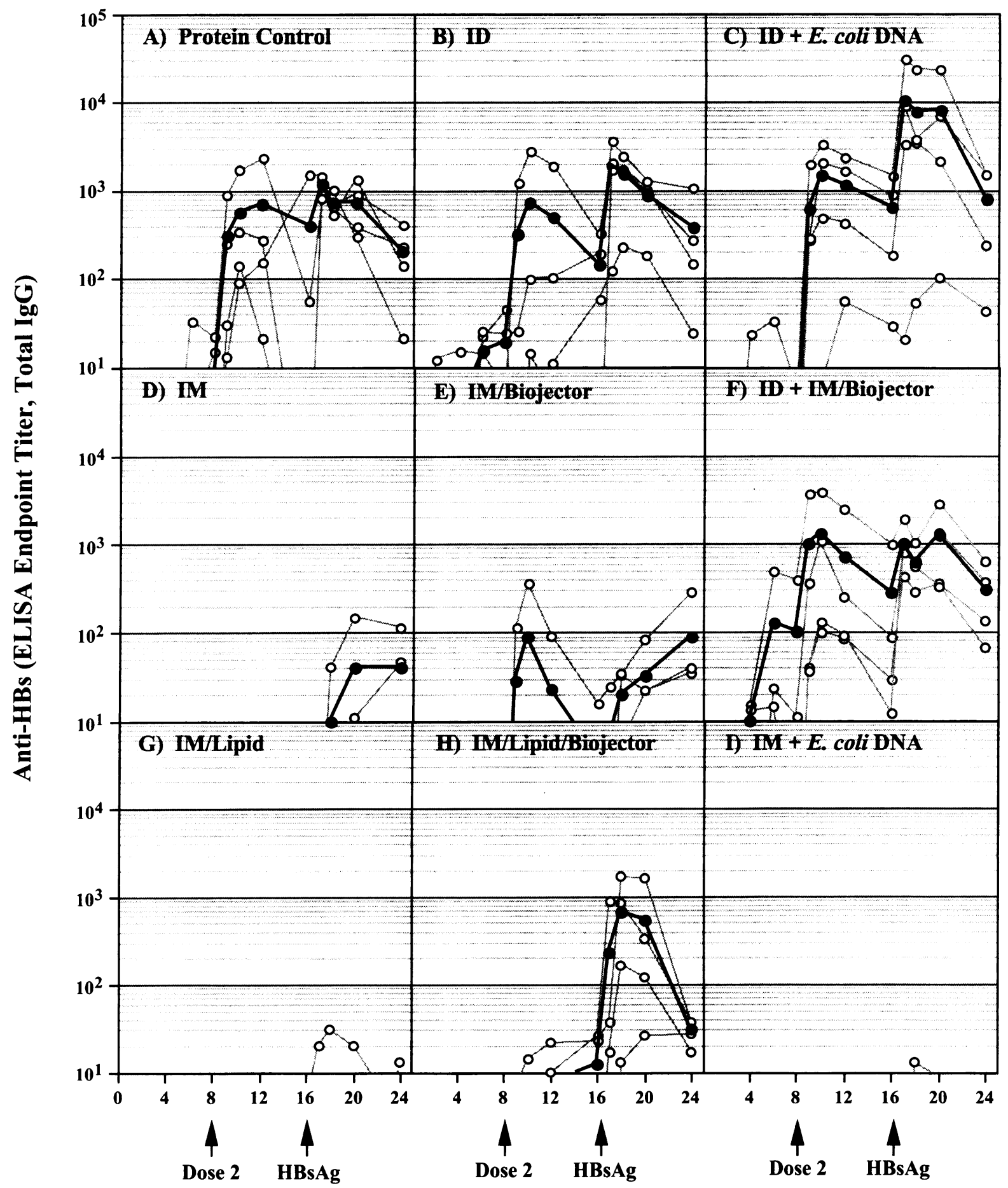

Time (weeks following immunization)

Fig. 1. Titers of anti-HBs antibodies (total IgG) in sera taken at various times from Aotus monkeys immunized at 0 and 8 weeks with an HBsAg-expressing DNA vaccine $(400 \mu \mathrm{g}$ pCMV $\left._{A}-S\right)$ or with HBsAg protein $(10 \mu \mathrm{g})$, and then with HBsAg at 16 weeks. The DNA vaccines were given by one of eight methods: (D) IM in saline with needle and syringe or (E) Biojector; $(G)$ IM associated with CellFECTIN with needle and sy- ringe or $(\mathrm{H})$ Biojector; (B) ID in saline with needle and syringe, (C) ID or (I) IM plus $E$. coli DNA (100 $\mu \mathrm{g})$ or (F) a combination of ID and IM/Biojector. Control animals received HBsAg (10 $\mu \mathrm{g})$ with alum for all three immunizations (A). Filled circles and black lines represent the group mean $(n=4)$. Open circles and gray lines indicate the values obtained for individual animals. 


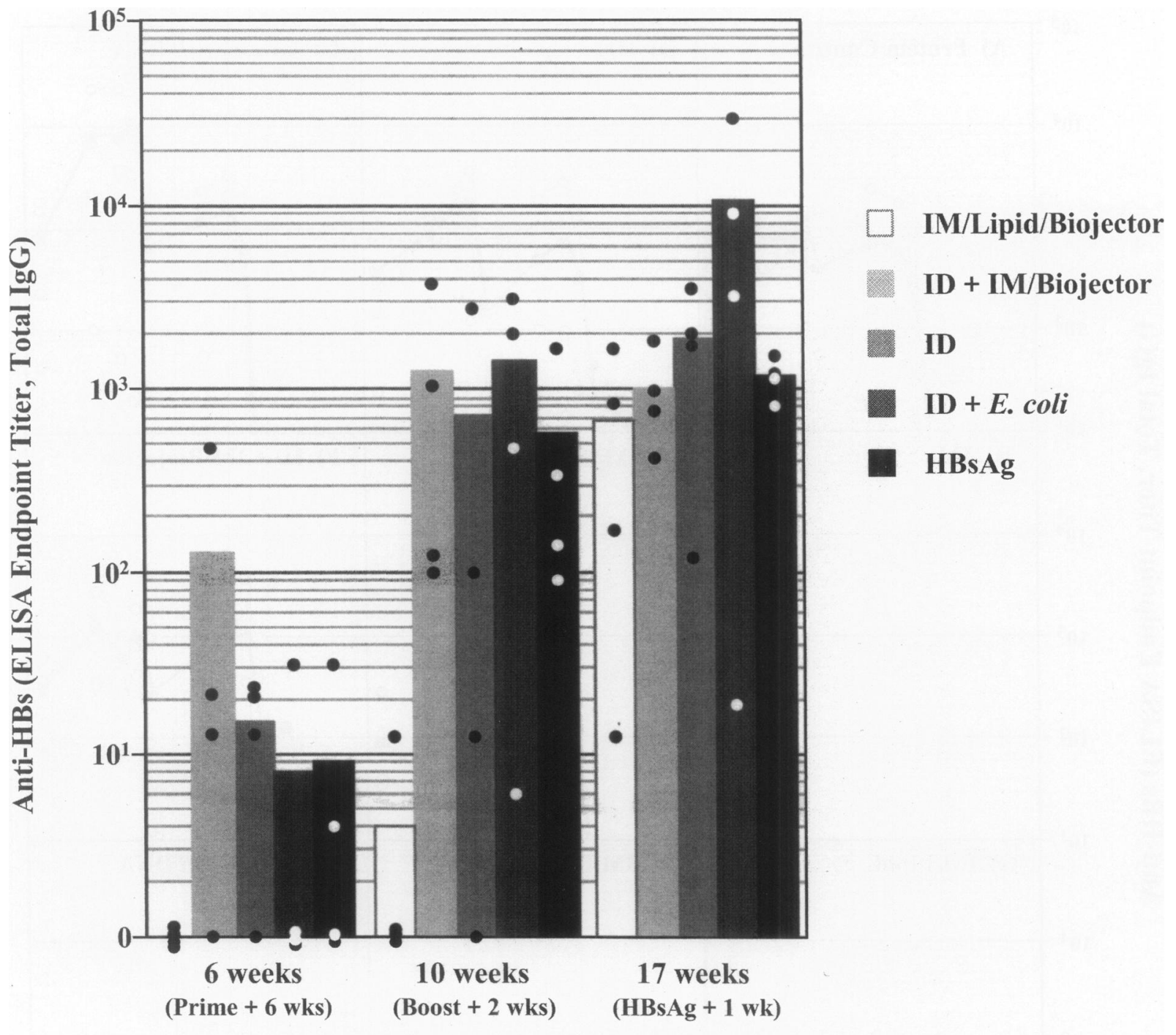

Time following immunization

Fig. 2. Titers of antibodies against hepatitis B surface antigen (HBsAg, anti-HBs, total IgG) in Aotus monkeys immunized at 0 and 8 weeks with either a DNA or protein (HBsAg, $10 \mu \mathrm{g}$ ) vaccine, then with HBsAg at 16 weeks. The DNA vaccine encoded HBsAg under the control of a cytomegalovirus promoter $\left(\mathrm{pCMV}_{\mathrm{A}}-\mathrm{S}\right)$ and each monkey received $400 \mu \mathrm{g}$ at each immunization. The DNA vaccines were given by (1) intramuscular injection of lipid-(CellFECTIN)-associated DNA using the Biojector needleless jet injection system [IM/lipid/ Biojector], (2) intradermal injection of DNA in saline

animal-namely, the efficiency of gene transfer and/or gene expression (i.e., the amount and form of antigen available) and the immune response to that antigen. In our ongoing efforts to optimize our HBV and malaria DNA vaccines for use in humans, we wished to evaluate different with a needle and syringe (ID) plus IM in saline with Biojector [IM/Biojector) [ID + IM/Biojector], (3) ID alone, or (4) ID with added $E$. coli DNA (100 $\mu \mathrm{g})[\mathrm{ID}+E$. coli]. Sera was taken at 6, 10, and 17 weeks (18 weeks for IM/lipid/Biojector) and assayed for anti-HBs by end-point dilution ELISA assay. Titers are expressed as the highest plasma dilution that resulted in an absorbance value (OD 450) two times greater than that of nonimmune sera from the same animal, with a cut-off value of 0.05 . Each bar represents the group mean $(n=4)$ and the dots indicate the values obtained for individual animals.

routes and formulations of DNA in nonhuman primates. Other than humans, only the great apes may be infected by HBV; however, orangutans are unacceptable for research use owing to their endangered status, and although chimpanzees may be bred in captivity, they are too ex- 
pensive to use in studies requiring large numbers of animals. For this reason, we chose to first evaluate various parameters in Aotus monkeys and to use our HBsAg-encoding DNA vaccine as this had been well characterized and there is a well-defined surrogate end point (15).

For malaria vaccine development, Aotus is an accepted model for Plasmodium falciparum ( $P$. falciparum) and $P$. vivax infections. Although Aotus monkeys are not suitable as an experimental hepatitis challenge model, this species appears to be a good model for HBV vaccines, at least with respect to immune responses to the antigen, in that their humoral responses to recombinant HBsAg (Engerix-B vaccine) are similar to those in humans. The seroconversion rates $(>10$ $\mathrm{mIU} / \mathrm{ml}$ or equivalent), which are $25 \%$ and $100 \%$ after prime and first boost, respectively, for the monkeys in the present study, compare well with the rates of $10 \%$ and $81 \%$ reported in a study on 42 humans (16). In humans, females are known to respond better than males to HBsAg, but no gender differences were noted for Aotus monkeys.

The suitability of the Aotus monkey as a model for humans with respect to efficiency of gene transfer and antigen expression is more difficult to ascertain. In mice, the HBsAg-expressing DNA vaccine works better when given IM than ID in equal doses (Brazolot Millan et al., unpublished observations). Here, we show that in Aotus monkeys, the ID route is better than IM, which essentially doesn't work unless the DNA formulation and method of delivery is optimized. This may not be very representative of the human situation, since IM-delivered DNA vaccines expressing $\mathrm{HBsAg}$ are effective in chimpanzees $(6,12)$ and Rhesus macaque monkeys (Brazolot Millan et al., unpublished observations). Furthermore, using a malaria DNA vaccine model in Aotus monkeys, we have found the IM route to be completely ineffective for induction of antibodies against $P$. yoelii and $P$. falciparum circumsporozoite protein (PyCSP, PfCSP), even though ID delivery of the same DNA vaccines or IM injection of a malaria multiple antigen peptide vaccine in adjuvant gives high levels of PyCSPor PfCSP-specific antibodies $(17,18)$ and the DNA vaccines also work IM in Rhesus macaques (Wang et al., submitted). The discrepant findings between Aotus and other nonhuman primates might be due in part to differences between Old World and New World species.

\section{Intramuscular versus Intradermal Delivery} of DNA Vaccines

Although IM delivery of naked DNA vaccines may be superior to ID in mice, notwithstanding the special situation of the Aotus monkey, this may or may not be true for primates. It is likely that muscle cytoarchitecture affects the efficiency of gene transfer, and one might imagine that the more extensive connective tissue required in larger and stronger animals for distribution of forces from myofibers to bones could interfere with direct gene transfer into muscle cells. This seems to be supported by our findings that luciferase reporter gene expression following plasmid DNA injection into fish muscle, which contains very little connective tissue, is 100 to 1,000 times higher than in mouse muscle injected with the same dose of DNA (Heppell et al., unpublished observations). Other investigators have also noted lower efficiency of transfection with plasmid DNA in primate than mouse muscle (19). Nevertheless, in addition to the HBsAg and malaria DNA vaccines mentioned above $(6,12,17,18)$, other DNA vaccines have been effective after IM delivery to nonhuman primates, including those encoding various proteins from influenza A or herpes simplex virus in African green monkeys (10) and from HIV/SIV in Rhesus macaque monkeys $(8,9,20)$ and chimpanzees $(5,7)$.

Another point to consider is that we are only evaluating humoral responses in this comparison of IM and ID DNA vaccine delivery. It is possible that results for cell-mediated immunity would give different results. Unfortunately, because of a lack of suitable reagents, it was not feasible to evaluate cell-mediated immune responses in the present study.

Humans are not as strong as other primates relative to body weight, and as such, may not be as severely limited by cytoarchitectural features. Nevertheless, investigators undertaking human clinical trials should be aware that this may pose a problem and should consider the ID route as an option for delivery of pure plasmid DNA vaccines to humans.

\section{Optimization of Intramuscular Delivery of DNA Vaccines}

We have tested three different approaches to optimize the humoral response in Aotus monkeys to the HBV DNA vaccine when delivered by IM injection: use of the Biojector needle-free jet in- 
jection system, use of liposome-formulated DNA, and addition of immunostimulatory E. coli DNA.

The Biojector system delivers solutions at a very high velocity and in a very thin stream, which pierces the skin and enters the muscle tissue. The distribution of the injected solution may be more widespread than that obtained with an ordinary needle and syringe, and this in turn may improve the response to a DNA vaccine, as has been found to be the case in rabbits (21). Although we have previously used the Biojector to successfully immunize chimpanzees (6) and Rhesus macaque monkeys (Brazolot Millan et al., unpublished results), these studies did not include an ordinary syringe group. In the present study, the DNA vaccine injected IM with syringe and needle failed to seroconvert any monkeys, even after a DNA boost, and the response to a subsequent dose of HBsAg protein indicated that only 2 of 4 monkeys had an anamnestic response. In contrast, Biojector delivery resulted in a fairly strong response in 1 monkey after the first boost, and evidence of an anamnestic response in 2 other monkeys. Thus it appears that the Biojector was superior to needle and syringe in the Aotus monkey.

With IM injection of naked DNA in mice, myocytes are clearly the predominant cell taking up and expressing the DNA; however, it is not clear to what extent nonmuscle cells are transfected and what role they might play in inducing immune responses. Although immunization with stably transfected muscle cells (i.e., antigen expressed solely in myocytes) can result in strong immune responses similar to those seen after DNA-based immunization, the muscle cells themselves are not responsible for antigen presentation (22-25). Thus, it is still possible that with IM injection of DNA vaccines there is direct transfection of nonmuscle cells such as professional antigen-presenting cells (APC) and that these cells are primarily responsible for the induction of immune responses. In fact, strong immune responses can be obtained by immunization solely with stably transfected dendritic cells (26), and this is likely the effector cell-type involved after ID or gene-gun delivery of DNA vaccines (27). Naked DNA transfects mature muscle fibers far more efficiently than mononuclear cells under in vivo conditions; however, the opposite is generally true of DNA formulated with cationic liposomes $(28,29)$. Thus, it might be possible to improve immune responses with IM delivery of DNA vaccines by use of liposomeformulated DNA through more efficient transfec- tion of nonmuscle cells, such as resident dendritic cells. In the present study, the use of liposomes with the DNA vaccine did not improve anti-HBs titers compared to naked DNA with either needle and syringe or Biojector delivery. However, the response to subsequent HBsAg protein indicates that when coupled with the Biojector, B cell priming is better using lipidformulated DNA than naked DNA.

\section{DNA as an Adjuvant to Augment Responses to DNA Vaccines}

It has been necessary to evaluate the optimization of DNA vaccines in a totally new light ever since the discovery by Krieg et al. (30) that unmethylated CpG dinucleotides within the context of certain flanking bases ( $\mathrm{CpG}$ motifs) have direct immunostimulatory effects on mouse splenocytes in vitro. Stimulatory $\mathrm{CpG}$ motifs, which are commonly found in bacterial DNA but are virtually absent from vertebrate DNA where there is CpG suppression and methylation, appear to have evolved as an adaptation to promote early immune activation subsequent to bacterial infection. Plasmid DNA, by virtue of its synthesis in bacteria, contains many unmethylated $\mathrm{CpG}$ dinucleotides and it has been shown that stimulatory $\mathrm{CpG}$ motifs are essential to the function of DNA vaccines (31-33). Immunostimulatory $\mathrm{CpG}$ motifs given as synthetic oligonucleotides have been shown to have potent stimulatory effects on both humoral and cell-mediated immunity in vivo and as such can be used as a vaccine adjuvant (34). CpG motifs are largely species-specific and those identified to work well on mouse cells do not generally have any effect on human cells in vitro (A. M. Krieg, personal communication). When this study was initiated, no potent human-specific motif had been identified, thus we chose to use $E$. coli DNA, which contains a wide range of $\mathrm{CpG}$ motifs and can stimulate human cells in vitro, as an adjuvant with the DNA vaccine. Although this did not improve humoral responses after IM injection of the DNA vaccine, after ID injection, more animals seroconverted and mean anti-HBs titers were 6-fold higher than with the DNA vaccine alone. To our knowledge, this is the first demonstration of in vivo immunostimulatory effects by CpG-rich DNA in a primate. The failure to detect a difference with IM administration may be due to inadequate transfection efficiency of the DNA vaccine in muscle tissue. It is also possible that there was down-regulation of the viral promoter by cyto- 
kines induced by the $E$. coli DNA. It is known that expression from the CMV promoter is reduced by cytokines such as the interferons $(35,36)$ and that bacterial DNA induces interferon- $\gamma$ production $(37,38)$. Under in vivo conditions, transfected myocytes within the highly vascular muscle tissue may be exposed to higher concentrations of cytokines than transfected cells in the relatively less vascular dermis.

\section{Summary and Implications for DNA Vaccines} in Humans

The findings of this study indicate that the efficacy of DNA vaccines in primates may be less efficient than in rodent models. Although the IM route works well in mice, ID may be a preferred route for primates; further research in other nonhuman primates, however, is necessary to ascertain this. Nevertheless, if low transfection efficiency is responsible for the poorer IM results in primates, there may be satisfactory antigen presentation but inadequate antigen load to stimulate B cells. In this case, a protein boost may prove beneficial, as long as there is a minimal transfection efficiency. It is also interesting to speculate that one might effectively prime immunity with a DNA vaccine and allow natural infection of the pathogen to evoke an anamnestic response. If the pre-patent or latent period is long enough, then the immune system may have sufficient time to mount an anamnestic response and protection would ensue. This may apply for pathogens with latencies of several weeks or months, like HBV and HIV. Malaria may also be a good candidate for this type of vaccine as the parasite replicates in the liver for approximately 7 days before continuing the next phase of its life cycle in the blood.

\section{Acknowledgments}

The authors thank Dr. Georg Widera (PowderJect Inc.) for providing the $\mathrm{pCMV}_{\mathrm{A}}-\mathrm{S}$ plasmid, Dr. Arthur Krieg (University of Iowa) for the E. coli DNA, Dr. Richard Stout (Bioject Inc.) for the Biojector needleless jet injection system, and Dr. Robert H. Purcell (NIAID, NIH) for the anti-New World monkey antibody. The Gorgas Memorial Laboratory authors in Panama thank Ms. G. Cisneros for laboratory technical assistance, Mr. C. Marin, Mr. R. Rojas, and Mr. T. Gonzales for their assistance in animal handling and care, and Ms. M. Brewer for her secretarial assistance. Technical assistance was also provided in Canada by Lacrimioara Comanita and Amanda Boyd.

This work was supported by the Naval Medical Research Institute and Development Command, work units 611102A.S13.00101-BFX. 1431 and 612787A.870.00101.EFX.1432, Army Contract DAMD17-91-C-1072. Support to H. L. D. was also provided through operating grants from MRC (Canada), a travel grant from Bioject Inc., and an Ontario Ministry of Health Career Scientist Award. The experiments reported here were conducted according to the principles set forth in the Guide for the Care and Use of Laboratory Animals, Institute of Laboratory Animal Resources, National Research Council (U.S. Department of Health and Human Services, Publ. National Institutes of Health 86-23, 1985). The opinions and assertions herein are of the authors and are not to be construed as official or as reflecting the views of the U.S. Navy or the Department of Defense.

\section{References}

1. Donnelly JJ, Ulmer JB, Shiver JW, Liu MA. (1997) DNA vaccines. Ann. Rev. Immunol. 15: 617-648.

2. Davis HL, Brazolot Millan CL. (1998) DNA-based immunization. Blood Cell Biochem. (in press).

3. Donnelly JJ, Ulmer JB, Liu MA. (1998) DNA vaccines. Life Sci. 60: 163-172.

4. Gregoriadis G, Saffie R, de Souza JB. (1997) Liposome-mediated DNA vaccination. FEBS Lett. 402: 107-1 10 .

5. Boyer JD, Ugen KE, Wang B, et al. (1997) Protection of chimpanzees from high-dose heterologous HIV-1 challenge by DNA vaccination. Nature Med. 3: $526-532$.

6. Davis HL, McCluskie MJ, Gerin JL, Purcell RH. (1996) DNA vaccine for hepatitis B: Evidence for immunogenicity in chimpanzees and comparison with other vaccines. Proc. Natl. Acad. Sci. U.S.A. 93: 7213-7218.

7. Fuller DH, Murphey-Corb M, Clements J, Barnett S, Haynes JR. (1996) Induction of immunodeficiency virus-specific immune responses in rhesus monkeys following gene gun-mediated DNA vaccination. J. Med. Primatol. 25: 236-241.

8. Lekutis C, Shiver JW, Liu MA, Letvin NL. (1997) HIV-1 env DNA vaccine administered to rhesus monkeys elicits MHC class II-restricted CD4+ T helper cells that secrete IFN-gamma and TNF-alpha. J. Immunol. 158: 4471-4477.

9. Liu MA, Yasutomi Y, Davies M-E, et al. (1996) Vaccination of mice and nonhuman primates using HIV-gene-containing DNA. In: Giraldo G, Bolognesi GP, Salvatore M, Beth-Giraldo E (eds). 
Development and Applications of Vaccines and Gene Therapy in AIDS. vol. 48. Karger, Basel, pp. 100104.

10. Liu MA, McClements W, Ulmer JB, Shiver J, Donnelly J. (1997) Immunization of non-human primates with DNA vaccines. Vaccine 15: 909-912.

11. Lu S, Arthos J, Montefiori DC, et al. (1996) Simian immunodeficiency virus DNA vaccine trial in macaques. J. Virol. 70: 3978-399l.

12. Prince AM, Whalen R, Brotman B. (1997) Successful DNA-based HBV immunization of newborn chimpanzees. Vaccine 15: 916-919.

13. Centers for Disease Control. (1987) Recommendations of the Immunization Practises Advisory Committee. Update on hepatitis B prevention. MMWR Morb. Mortal. Wkly. Rep. 36: 353.

14. Calandra GB, West DJ. (1993) Recommendations for prevention of hepatitis B with vaccine. In: Ellis RW (ed). Hepatitis B Vaccines in Clinical Practice. Marcel Dekker, Inc., New York, pp. 1-16.

15. Davis HL. (1996) DNA-based vaccination against hepatitis B virus. Adv. Drug Delivery 21: 33-47.

16. Guan R. (1989) Comparison of the immunogenicity of the $5 \mu \mathrm{g}$ dose and $10 \mu \mathrm{g}$ dose MSD rDNA hepatitis B vaccine (Hepavac II). Epidemiol. News Bull. 15: 24-26.

17. Gramzinski RA, Maris DC, Obaldia N, et al. (1996) Optimization of antibody responses of a malaria DNA vaccine in Aotus monkeys. Vaccine Res. 5: 173-183.

18. Gramzinski RA, Maris DC, Doolan D. et al. (1997) Malaria DNA vaccines in Aotus monkeys. Vaccine 15: 913-915.

19. Jiao S, Williams P, Berg RK, et al. (1992) Direct gene transfer into nonhuman primate myofibers in vivo. Hum. Gene Ther. 3: 21-33.

20. Yasutomi Y, Robinson HL, Lu SS, et al. (1996) Simian immunodeficiency virus-specific cytotoxic T-lymphocyte induction through DNA vaccination of rhesus monkeys. J. Virol 70: 678-681.

21. Davis HL, Michel ML, Mancini M, Schleef $M$, Whalen RG. (1994) Direct gene transfer in muscle with plasmid DNA for the purpose of nucleic acid immunization. Vaccine 12: 1503-1509.

22. Doe B, Selby S, Barnett J, Baenziger J, Walker CM. (1996) Induction of cytotoxic T lymphocytes by intramuscular immunization with plasmid DNA is facilitated by bone marrow-derived cells. Proc. Natl. Acad. Sci. U.S.A. 93: 8578-8583.

23. Corr M, Lee DJ, Carson DA, Tighe H. (1996) Gene vaccination with naked plasmid DNA: Mechanism of CTL priming. J. Exp. Med. 184: 1555-1560.

24. Ulmer JB, Deck RR, DeWitt CM, Donnelly JJ, Liu MA. (1996) Generation of MHC class-I restricted T lymphocytes by expression of a viral protein in muscle cells: antigen presentation by non-muscle cells. Immunology 89: 59-67.

25. Iwasaki A, Torres CAT, Ohashi P, Robinson HL, Barber BH. (1997) The dominant role of bone- marrow derived cells in CTL induction following plasmid DNA immunization at different sites. J. Immunol. 159: 11-14.

26. Manickan E, Kanangat S, Rouse RJ, Yu Z, Rouse BT. (1997) Enhancement of immune response to naked DNA vaccine by immunization with transfected dendritic cells. J. Leukoc. Biol. 61: 125-132.

27. Condon C, Watkins SC, Celluzzi CM, Thompson K, Falo LD. (1996) DNA-based immunization by in vivo transfection of dendritic cells. Nature Med. 2: 1122-1128.

28. McCluskie MJ, Davis HL (1998) DNA-based immunization of mice against HBV by intramuscular injection requires free DNA. In: Brown $F$, Burton D, Doherty P, Mekalanos J, Norrby E (eds). Vaccines 97: Molecular Approaches to the Control of Infectious Diseases. Cold Spring Harbour Laboratory Press, New York, pp. 125-130.

29. Wolff JA, Malone RW, Williams P, et al. (1990) Direct gene transfer into mouse muscle in vivo. Science 247: 1465-1468.

30. Krieg AM, Yi A-K, Matson S, et al. (1995) CpG motifs in bacterial DNA trigger direct B-cell activation. Nature 374: 546-549.

31. Klinman DM, Yamshchikov G, Ishigatsubo Y. (1997) Contribution of CpG motifs to the immunogenicity of DNA vaccines. J. Immunol. 158: 3635-3639.

32. Sato $Y$, Roman $M$, Tighe $H$, et al. (1996) Immunostimulatory DNA sequences necessary for effective intradermal gene immunization. Science 273: 352-354.

33. Roman M, Martinorozco E, Goodman S, et al. (1997) Immunostimulatory DNA sequences function as T helper-1-promoting adjuvants. Nature Med. 3: 849-854.

34. Davis HL, Weeratna R, Waldschmidt TJ, Schorr J, Krieg AM. (1998) CpG DNA is a potent adjuvant in mice immunized with recombinant hepatitis $B$ surface antigen. J. Immunol. 160: 870-876.

35. Gribaudo G, Ravaglia S, Caliendo A, et al. (1993) Interferons inhibit onset of murine cytomegalovirus immediate-early gene transcription. Virology 197: 303-311.

36. Harms JS, Splitter GA. (1995) Interferon-gamma inhibits transgene expression driven by SV40 or CMV promoters but augments expression driven by the mammalian MHC I promoter. Hum. Gene Ther. 6: 1291-1297.

37. Cowdery JS, Chace JH, Yi A-K, Krieg AM. (1996) Bacterial DNA induces NK cells to produce interferon-yin vivo and increases the toxicity of lipopolysaccharide. J. Immunol. 156: 4570-4575.

38. Halpern MD, Kurlander RJ, Pisetsky DS. (1996) Bacterial DNA induces murine interferon- $\gamma$ production by stimulation of interleukin-12 and tumor necrosis factor- $\alpha$. Cell Immunol. 167: 7278. 